Simon MacLean

Dept of Mediaeval History,

71 South St,

St Andrews,

Fife KY16 9AL

\title{
Insinuation, Censorship and the Struggle for Late Carolingian Lotharingia in Regino of Prüm's Chronicle
}

In the early middle ages historiography was a self-justifying genre. History, being true, was its own virtue, and as such valued for the spiritual, scriptural and political truths it could reveal to the present. ${ }^{1}$ Yet at the same time it often provided a vehicle for more specific political argument, since the people who wrote it were members of educated elites whose careers almost inevitably involved them in intrigue and conflict. For example, Guy Halsall has recently shown how profoundly the method and narrative strategies of the late-sixth-century historian Gregory of Tours were affected by the delicate political situation in which he wrote, and in particular by his fear of the

\footnotetext{
* For their advice and criticism I gratefully acknowledge the help of Stuart Airlie, Matthew Innes, Julia Smith and Jinty Nelson. This article was completed with the help of a Research Leave grant from the Arts and Humanities Research Council.

${ }^{1}$ For discussion see Y. Hen and M. Innes, eds., The Uses of the Past in the Early Middle Ages (Cambridge, 2000); R. McKitterick, History and Memory in the Carolingian World (Cambridge, 2004); W. Goffart, 'Bede's vera lex historiae Explained', Anglo-Saxon England, xxxiv (2005), 111-16.
} 
Merovingian king Guntram. ${ }^{2}$ Similarly, as Janet Nelson's classic study demonstrated, the intricate narrative of the mid-ninth century civil wars composed by the Frankish layman Nithard has to be understood in light of his escalating dissatisfaction with the peace settlement brokered by his king Charles the Bald. ${ }^{3}$ Although the vicissitudes of these authors' careers and the substance of their scholarship were thoroughly intertwined, neither could afford to be openly polemical. In a literary culture where the relationship between author and audience was much closer and less impersonal than in modern publishing, the very same circumstances that compelled such authors to thread their texts with narratives of personal grievance also forced them to suppress their complaints. However betrayed Nithard felt by his lord, Charles the Bald remained ruler of west Francia, while Guntram's control of Tours made open criticism of him (or open praise of his rivals) unthinkable for Gregory. Gregory and Nithard thus wrote about, and in the midst of, dangerous situations which demanded their expressions of discontent be left coded and semi-submerged. By writing themselves into their own narratives and by deploying carefully chosen allusions and hints, they insinuated criticisms at those they resented without making their hostility explicit. These 'private histories', as Nelson has called them, take us to the heart of contemporary political controversies, but the passage of time means that, for us, their outlines can be frustratingly indistinct: modern historians

\footnotetext{
${ }^{2}$ G. Halsall, 'Nero and Herod? The Death of Chilperic and Gregory of Tours' Writing of History', in K. Mitchell and I.N. Wood, eds., The World of Gregory of Tours (Leiden, 2002), 337-350; G. Halsall, 'The Preface to Book V of Gregory of Tours' Histories: Its Form, Content and Significance', ante, cxxii (2007), 297-317. See also I.N. Wood, 'The Secret Histories of Gregory of Tours', Revue Belge de Philologie et d'Histoire, lxxi (1993), 253-70.

${ }^{3}$ J.L. Nelson, 'Public Histories and Private History in the Work of Nithard', Speculum, lx (1985), 251-93.
} 
can only reconstruct them by picking up hints dropped centuries ago and placing them carefully back into context. Decoding their private stories is an essential prelude to understanding the purposes and rhetorical strategies of such authors' 'public' histories.

This article is concerned with the uneasy career of Abbot Regino of Prüm (d. 915), another major historian whose work ripples, like those of Gregory and Nithard, with political tension and insinuation, but whose text and troubles have not, despite many attempts, been satisfactorily explained. ${ }^{4}$ Regino lived in the shattered political landscape of post-imperial Lotharingia. Since 751 the Frankish Empire, which at its fullest extent in the ninth century covered most of mainland western Europe, had been ruled exclusively by members of the Carolingian dynasty. Lotharingia was a by-product of the empire's division into eastern, western and middle kingdoms between the grandsons of the emperor Charlemagne in 843. Comprising the northern part of the middle kingdom and stretching from the Low Countries to Provence, it took its name from King Lothar II (855-69). Although Lothar's premature death in 869 without legitimate heir meant that within a year his kingdom had been carved up by his predatory uncles and apportioned to

\footnotetext{
${ }^{4}$ For overviews of Regino's career and works see H. Hüschen, 'Regino von Prüm, Historiker, Kirchenrechtler und Musiktheoretiker', in H. Hüschen, ed., Festschrift Karl Gustav Fellerer zum sechzigsten Geburtstag (Regensburg, 1962), 205-23; E. Hlawitschka, 'Regino von Prüm (gest. 915)', Rheinische Lebensbilder, vi (1975), 7-27; G. Schmitz, 'Regino von Prüm', in Verfasserlexikon (2 ${ }^{\text {nd }}$ ed., 1989), vol. 7, col. 1115-22; B. Schneidmüller, 'Regino von Prüm', in Handwörterbuch zur deutschen Rechtsgeschichte (1990), vol. 4, col. 492-5; W. Wattenbach, W. Levison and H. Löwe, Deutschlands Geschichtsquellen im Mittelalter, vol. 6 (Weimar, 1990), 897-904; W. Hartmann, 'Regino von Prüm', in Neue deutsche Biographie, 21 (2003), 269-70.
} 
the eastern and western realms, Lotharingia's elites appear to have retained a sense of regnal identity that persisted into the late ninth and tenth centuries, when it found political expression once more under the leadership of a series of subordinate kings and duces ('dukes'). ${ }^{5}$ The Carolingian political system was flexible enough to survive the numerous territorial partitions, like those of 843 and 870 , that studded ninth-century history, and to accommodate a variety of regnal identities under its Frankish umbrella. But things changed decisively when the dynastic hegemony which underwrote that system was destroyed in $887-8$ by the deposition and death of the last Carolingian emperor Charles III 'the Fat'. The absence of legitimate male Carolingians to fill the considerable gap left by Charles caused the empire to split definitively into smaller kingdoms ruled by kings drawn from a variety of families, whose equality of legitimacy and power was a major source of conflict. Regino's $\underline{\text { Chronicle, }}$ completed in 908, provides the classic account of this development:

After [Charles's] death the kingdoms which had obeyed his authority, just as though a legitimate heir were lacking, dissolved into separate parts and, without waiting for their natural lord, each decided to create a king from its own guts. This was the cause of great wars; not because the Franks lacked leaders who by nobility, courage and wisdom were capable of ruling the kingdoms, but rather because the equality of descent, authority and power increased the discord among them; none so outshone the others that the rest deigned to submit to his rule. For Francia would have

\footnotetext{
${ }^{5}$ See H.-W. Herrmann and R. Schneider, eds., Lotharingia. Eine europäische Kernlandschaft um das Jahr 1000 (Saarbrücken, 1995).
} 
produced many leaders capable of controlling the government of the kingdom, had not fortune equipped them to destroy each other in the competition for power. ${ }^{6}$

The countryside of Lotharingia bristled with prestigious churches, palaces and estates, and consequently experienced at least as much conflict as any part of the former empire. ${ }^{7}$ The major imperial monastery of Prüm sat in the thick of the action, nestled as it was at the heart of an important royal and aristocratic landscape in the Ardennes, not far from

\footnotetext{
${ }^{6}$ Regino, Chronicle, ed. F. Kurze, Reginonis abbatis Prumiensis Chronicon cum continuatione Treverensi, M[onumenta] G[ermaniae] H[istorica] S[criptores] R[erum] G[ermanicarum in usum scholarum separatism editi] (Hanover, 1890), s.a. 888, 129: 'Post cuius mortem regna, que eius ditioni paruerant, veluti legitimo destitute herede, in partes a sua compage resolvuntur et iam non naturalem dominum prestolantur, sed unumquodque de suis visceribus regem sibi creari disponit. Quae causa magnos bellorum motus excitavit; non quia principes Francorum deessent, qui nobilitate, fortitudine et sapientia regnis imperare possent, sed quia inter ipsos aequalitas generositatis, dignitatis ac potentiae discordiam augebat, nemine tantum ceteros precellente, ut eius dominio reliqui se submittere dignarentur. Multos enim idoneos principes ad regni gubernacula moderanda Francia genuisset, nisi fortuna eos aemulatione virtutis in pernitiem mutuam armasset.' For discussion of this passage and its implications see H.-H. Kortüm, 'Multi reguli in Europa...excrevere. Das ostfränkische Reich und seine Nachbarn', in F. Fuchs and P. Schmid, eds., Kaiser Arnolf. Das ostfränkische Reich am Ende des 9. Jahrhunderts (Munich, 2002), 68-88; S. Airlie, 'Les élites en 888 et après, ou comment pense-t-on la crise carolingienne?', in F. Bougard, L. Feller and R. Le Jan, eds., Les Elites au Haut Moyen Age. Crises et Renouvellements (Turnhout, 2006), 425-37.

${ }^{7}$ The fundamental studies include R. Parisot, Le Royaume de Lorraine sous les Carolingiens (843-923) (Paris, 1898); E. Ewig, Frühes Mittelalter (Rhenische Geschichte I.2) (Dusseldorf, 1980), 187-200; H.H. Anton, Trier im frühen Mittelalter (Paderborn, 1987).
} 
the great Carolingian palace of Aachen. ${ }^{8}$ Regino's was a world pounded from without by the raids of Scandinavians and Hungarians, and torn apart from within by violent feuds and the disruption of political process. Lotharingia, although nominally part of the eastern kingdom, was an attractive prize to the rulers of both east and west Francia, who from their distant palaces in Frankfurt, Regensburg, Paris and Laon regularly converged to fight for its control. The kings Regino chronicled were thus often off-stage to east or west and were not around to prevent leading aristocrats from being murdered in churches or on the toilet, nor save powerful abbots from being driven out of their monasteries. Regino, forcibly ejected from Prüm in 899 , was one such abbot. His eviction was no trivial matter, for Prüm was a Carolingian family foundation. Established in 721, it boasted close links with the dynasty and had been able to depend on the patronage of successive rulers ever since a generous endowment from the first Carolingian king Pippin in 762. ${ }^{9}$ The monastery therefore carried both symbolic and economic value in the struggle for power in fin de siècle Lotharingia. Regino was an actor in that struggle and his $\underline{\text { Chronicle, }}$ which contains allusions to the enemies and rivals he believed responsible

\footnotetext{
${ }^{8}$ E. Ewig, 'Les Ardennes au haut Moyen-Âge', in E. Ewig, Spätantikes und fränkisches Gallien: gesammelte Schriften (1952-1973), ed. H. Atsma (Munich, 1976-9), vol. 1, 523-52.

${ }^{9}$ E. Mühlbacher, (ed.), Die Urkunden Pippins, Karlmanns und Karls des Grossen, MGH Diplomata Karolinorum 1 (Hanover, 1906), Pippin nos. 3, 16. On Prüm and the early Carolingians see most recently M. Garrison, 'The Franks as the New Israel? Education for an Identity from Pippin to Charlemagne', in Hen and Innes, eds., Uses of the Past, 114-61 at 131-3; S. Airlie, 'Towards a Carolingian Aristocracy', in M. Becher and J. Jarnut, eds., Der Dynastiewechsel von 751. Vorgeschichte, Legitimationsstrategien und Erinnerung (Münster, 2004), 109-127.
} 
for his downfall, must be read with this in mind: the text itself was part of the political conflict of which it purported to be a detached description.

In this context historians have had cause to lament that a section of text purporting to explain the abbot's fate in detail was mysteriously erased from his work at some stage and does not survive in any of the 30 extant manuscripts. ${ }^{10}$ Rather than acting as a deterrent this mystery has inspired numerous attempts to explain Regino's downfall, but the most recent specialist to tackle the problem has concluded that the dynamics leading to the abbot's fall from grace must remain forever opaque. ${ }^{11}$ In what follows I will argue that, on the contrary, the Chronicle itself, properly interrogated, can provide us with fresh insights into contemporary politics, and that historians have been asking the wrong questions of this crucial text. After introducing the main features of the Chronicle the article will proceed to an analysis of the work's apparent censorship. The implications of this for how we view the circumstances of Regino's ejection will then be drawn out, and it will be argued that an appreciation of the text's rhetorical strategies, particularly juxtaposition and insinuation, provides further important insights. Finally, we will turn to the issue of how and why the abbot wrote his history in the way that he did. By analysing his $\underline{\text { Chronicle }}$ specifically as a source for its author's troubled career - by trying to excavate his 'private history' - I aim not only to resolve some of the puzzles presented by

\footnotetext{
${ }^{10}$ W.-R. Schleidgen, Die Überlieferungsgeschichte der Chronik des Regino von Prüm (Mainz, 1977) describes the manuscripts.

${ }^{11}$ Hartmann, 'Regino'.
} 
the text itself, but also to illuminate the dissolution of Frankish politics in a heartland of the former empire.

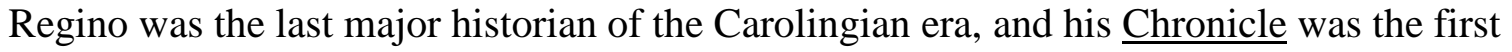
complete account of the empire's rise and fall. ${ }^{12}$ The work is divided into two books. The first, 'On the times of the Lord's incarnation', begins with the birth of Christ and comprises a broad narrative about the fortunes of rulers and churchmen organised according to the regnal spans of Roman and Byzantine emperors. Book I is constructed almost exclusively from excerpts of earlier authorities (the chronological scheme, for example, is modelled on Bede's Greater Chronicle) and ends in 741 with the death of Charles Martel, father of the first Carolingian king Pippin. Book II ('On the deeds of the kings of the Franks') incorporates a faithful transcription of the Royal Frankish Annals for the era between Charles Martel's death and that of Pippin's son Charlemagne in 814, but thereafter turns into an independent account of Frankish history structured in broadly annalistic fashion. ${ }^{13}$ From the middle of the ninth century until the final entry in 906 the

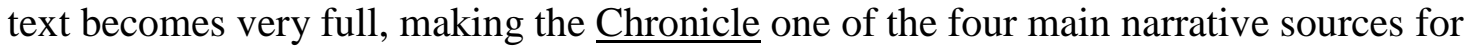
the later Carolingian Empire, and arguably (thanks to the inclusion of detailed anecdotes collected from Regino's monastic 'elders') the most colourful. The text's subject-matter is broadly characteristic of contemporary historiography: the deeds of kings, the heroes of

\footnotetext{
${ }^{12}$ As pointed out by S. Airlie, "'Sad stories of the deaths of kings": Narrative Patterns and Structures of Authority in Regino of Prüm's Chronicle', in E.M. Tyler and R. Balzaretti, eds., Narrative and History in the Early Medieval West (Turnhout, 2006), 105-31.

${ }^{13}$ One version of the Royal Frankish Annals in circulation during the ninth century stopped at the death of Charlemagne: McKitterick, History and Memory, 20, 111-13.
} 
the church and the depredations of hostile Scandinavians and Bretons feature prominently. This standard palette takes on more nuance in view of Regino's intended audience. The fact that he dedicated the finished work in 908 to Bishop Adalbero of Augsburg suggests that he intended it for the attention of King Louis IV 'the Child' of east Francia (b. 893, r. 900-911). Adalbero was described in royal charters as the young king's 'nutritor' ('nourisher' / 'upbringer' / 'foster-father'), and together with Archbishops Hatto of Mainz and Ratbod of Trier formed the heart of something like a de $\underline{\text { facto }}$ regency council. ${ }^{14}$ The Chronicle's exemplary and admonitory stories may thus have been meant to instruct the young king. In writing history as a manual for kingly conduct, Regino worked in the tradition of illustrious Carolingian predecessors like Frechulf of Lisieux, who hoped the second book of his world history (c. 830) would be used in the education of the six-year-old Charles the Bald. ${ }^{15}$ Such motivations were not unique to Carolingian authors. In fact, the desire of churchmen to instruct rulers in the interpretation of divine will and the responsibilities of leading a chosen people to

\footnotetext{
${ }^{14}$ T. Schieffer, ed., Die Urkunden Zwentibolds und Ludwigs des Kindes, MGH Diplomata Regum Germaniae ex Stirpe Karolinorum IV (Berlin, 1960), Louis the Child nos. 4, 9, 65; Airlie, 'Narrative Patterns', 111-12. Ratbod was leader of the royal chancery: T. Schieffer, 'Die lothringische Kanzlei um 900', Deutsches Archiv für Erforschung des Mittelalters, xiv (1958), 16-148. On the reign of Louis the Child see now T. Offergeld, Reges pueri: das Königtum Minderjähriger im frühen Mittelalter (Hanover, 2001), 518-641.

${ }^{15}$ Frechulf of Lisieux, Histories, ed. M. Allen, Frechulfi Lexoviensis episcopi opera omnia, Corpus Christianorum Continuatio Mediaevalis vol. 169A (Turnhout, 2002), 435-7.
} 
salvation can be seen as one of the defining features of early medieval historiography in general. $^{16}$

His chronicle's generic similarity to other contemporary historical works can make us miss the fact that Regino was a historian of some originality. He was, for instance, the first major author to begin a history with the birth of Christ, and the first to attempt a comprehensive AD chronology for the entire period since. ${ }^{17}$ These original features distinguish the $\underline{\text { Chronicle }}$ as a text of great import and interest, but while Book II's picturesque anecdotes and wealth of detail have been readily plundered as a quarry of information on later ninth-century affairs, the work as a whole is less well appreciated by modern scholars. Although the great nineteenth-century scholar Ernst Dümmler placed

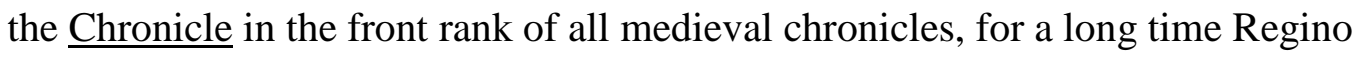
remained much more celebrated for his influential handbooks on canon law and music

\footnotetext{
${ }^{16}$ K.F. Werner, 'Gott, Herrscher und Historiograph: Der Geschichtsschreiber als Interpret des Wirken Gottes in der Welt und Ratgeber der Könige, 4-12 Jht.', in E.-D.Hehl, H. Seibert and F. Staab, eds., Deus qui mutat tempora: Menschen und Institutionen im Wandel des Mittelalters. Festschrift A. Becker
} (Sigmaringen, 1987), 1-31; K.F. Werner, 'Dieu, les rois et l'histoire', in R. Delort, ed., La France de l'an Mil (Paris, 1990), 264-81.

${ }^{17}$ On Regino as a historian see A.-D. von den Brincken, Studien zur lateinischen Weltchronik bis in das Zeitalter Ottos von Freising (Dusseldorf, 1957), 128-33; H.-W. Goetz, 'Vergangenheitswahrnehmung, Vergangenheitsgebrauch und Geschichtssymbolismus in der Geschichtsschreibung der Karolingerzeit', Settimane di studio della Fondazione Centro Italia, xlvi (1999), 177-225 at 191-2, 204, 223; R. McKitterick, Perceptions of the Past in the Early Middle Ages (Notre Dame, 2006), 30-3, 38-42; S. MacLean, History and Politics in Late Carolingian and Ottonian Europe: the Chronicle of Regino of Prüm and Adalbert of Magdeburg (Manchester, 2009). 
than for his work as a historian. ${ }^{18}$ Lately, a revival of interest in the Chronicle has confirmed Dümmler's estimation of its significance. Hans-Werner Goetz and Rosamond McKitterick have rightly emphasised the need to understand the work as a single text bound together by unifying themes, a point missed by those who concentrate exclusively on its second book. ${ }^{19}$ Meanwhile, Stuart Airlie's very subtle and important analysis of Regino's narrative strategies has drawn attention to the Chronicle's extremely meticulous structure. Despite its annalistic format, the work was conceived as a single piece whose ending was pre-ordained and whose entire narrative was coloured by the end of the empire in 888. Regino thus inhabited the persona of a 'master narrator', orchestrating an ironic history of the causes and consequences of imperial fragmentation full of flashesforward and knowing allusions. ${ }^{20}$

The sophistication of its construction and its use of irony must be borne in mind when we interrogate the Chronicle about its author's political career. Nothing is known about Regino's family background, though he was probably noble and a tradition recorded in the sixteenth century suggests he was born at Altrip, a Prüm estate near Speyer. Thanks to the survival of lists of monks from the abbacy of Ansbald (860-86) we can dimly observe his rise through the ranks in the years before 892 , when he became abbot with the approval of King Arnulf of east Francia (887-99). ${ }^{21}$ We know little about his abbacy

\footnotetext{
${ }^{18}$ E. Dümmler, Geschichte des ostfränkischen Reiches ( $2^{\text {nd }}$ ed., Leipzig 1887-8), vol. 3, 657.

${ }^{19}$ See above, n. 17.

${ }^{20}$ Airlie, 'Narrative Patterns'.

${ }^{21}$ G. Tellenbach, 'Der Konvent der Reichsabtei Prüm unter Abt Ansbald (860-886)', in G. Tellenbach, Ausgewählte Abhandlungen und Aufsätze (Stuttgart, 1988), vol. 2, 411-25.
} 
other than that he presided over the completion of a major estate survey in 893 (probably thought necessary after Viking attacks on the abbey in 882 and 892); and that sometime between 895 and 900 he was entrusted with custody of the blinded Carolingian pretender Hugh, illegitimate son of Lothar II. ${ }^{22}$ Both facts highlight the considerable resources and political status enjoyed by abbots of houses like Prüm, whose wealth and connections thoroughly integrated them into the wider political world. In view of the fragmented political scene in post-888 Lotharingia, this status was by no means guaranteed. Even after 895, when he managed to have his illegitimate son Zwentibald installed as ruler of Lotharingia, King Arnulf found it difficult to assert his authority in what was effectively a peripheral part of his realm (his own power-bases lay further east in Bavaria and the Rhineland). As a result he faced repeated challenges for its control from the king of west Francia, Odo (888-98), and from Odo’s rival and eventual successor Charles 'the Straightforward' (898-923, d. 929). ${ }^{23}$ The ensuing struggle for power was punctuated by a series of shocking murders. On 28 August 892 Megingoz, a powerful count who had established himself as the dominant royal middleman in Lotharingia, was killed in the

\footnotetext{
${ }^{22}$ I. Schwab, ed., Das Prümer Urbar (Dusseldorf, 1983); Regino, Chronicle, s.a. 885, 125. On Regino as abbot see now E. Wisplinghoff, 'Untersuchungen zur Geschichte des Klosters Prüm an der Wende vom 9. zum 10. Jahrhundert', Deutsches Archiv für Erforschung des Mittelalters, lv (1999), 439-75, though his arguments against Regino's involvement in the estate survey stretch the evidence considerably.

${ }^{23}$ I refer to Charles as 'the Straightforward' rather than 'the Simple' following B. Schneidmüller, 'Die “Einfältigkeit” Karls III von Westfrankreich als frühmittelalterliche Herrschertugend. Überlegungen zu den cognomen simplex', Schweizerische Zeitschrift für Geschichte, xxviii (1978), 62-6. Doubts are raised about this translation of the epithet 'simplex' by G. Koziol, 'Is Robert I in Hell? The Diploma for Saint-Denis and the Mind of a Rebel King (Jan. 25, 923)', Early Medieval Europe, xiv (2006), 233-67, at 238, n. 14, but Regino uses the term on several occasions as a positive royal attribute.
} 
monastery of St-Sixtus at Rethel. The assassination must have been carefully orchestrated for maximum impact, for 28 August was the anniversary of the death of Megingoz's former lord (and Arnulf's grandfather), the great east Frankish ruler Louis the German (840-76). Four years later the murderer, Alberic, received a taste of his own medicine, again on a significant festival, at the hands of another count called Stephen; and in 901 the latter was himself assassinated by persons unknown whilst evacuating his bowels in the privy. ${ }^{24}$ All these killings were motivated by the desire of excluded cliques to gain access to royal patronage by removing and taking over from those who monopolized it: incubated by the absentee kingship of recent years, Lotharingian politics had become deeply factionalised. Arnulf and Zwentibald therefore found it impossible to draw all groups into the political system in traditional Carolingian fashion and were instead forced to play aristocratic factions off against each other and try to rule through local middlemen. ${ }^{25}$ This was a dangerous game which Zwentibald played with a heavy hand, gaining him a reputation as an unpredictable and capricious ruler. According to Regino, no doubt somewhat hyperbolically: 'He was running the affairs of the realm with women and the lesser-born, deposing all the more honourable and noble people and

\footnotetext{
${ }^{24}$ Regino, Chronicle, s.a. 892, 896, 901, 140, 144, 149.

${ }^{25}$ Ewig, Frühes Mittelalter, 191; M. Innes, State and Society in the Early Middle Ages: the Middle Rhine Valley, 400-1000 (Cambridge, 2000), 222-41; M. Innes, 'People, Places and Power in the Carolingian World: a Microcosm', in M. de Jong and F. Theuws, eds., Topographies of Power in the Early Middle Ages (Leiden, Boston and Cologne, 2001), 397-437.
} 
stripping them of offices and dignities. For this reason he became hated by everyone. ${ }^{, 26}$ Ultimately, in 900, Zwentibald himself was killed.

Despite - or more likely because of - his evident political standing, Regino was dragged into the turmoil. The immediate instigators of his downfall, as the Chronicle makes clear, were Gerard and Matfrid, powerful regional nobles based in the Moselle valley, who installed in his place their brother Richar. These three men were leading representatives of a family known to historians as the Matfridings. Such modern labels are terms of art and should not be taken to mean that family relationships inevitably determined political allegiance. Nonetheless, in this case Regino makes it clear that the Matfridings were at the heart of a coherent faction that also included Alberic's murderer Stephen, count in the Bidgau near Trier. ${ }^{27}$ This group was never far from the action in the later 890s. In 896-7 a group of aristocrats centred on Stephen, Gerard and Matfrid was dispossessed by and then reconciled with Zwentibald; and in 900 the same three men led the group responsible for the king's death. ${ }^{28}$ The prominence of these men leaves little doubt that Regino's fate too was intimately connected with the wider currents of Lotharingian power-politics. After his deposition, the abbot was taken in by Archbishop Ratbod, who

\footnotetext{
${ }^{26}$ Regino, Chronicle, s.a. 900, 148: 'Cum mulieribus et ignobilioribus regni negotia disponens honestiores et nobiliores quosque deiciebat et honoribus et dignitatibus expoliabat. Pro huiuscemodi itaque causa omnibus odiosus efficitur.'

${ }^{27}$ On the Matfridings see E. Hlawitschka, Lotharingien und das Reich an der Schwelle der deutschen Geschichte (Stuttgart, 1968), 166-74; E. Hlawitschka, Die Anfänge des Hauses Habsburg-Lothringen (Saarbrücken, 1969), 154-71.

${ }^{28}$ Regino, Chronicle, s.a. 897, 900, 144-5, 148.
} 
put him in charge of the monastery of St-Martin in Trier, a considerably less prestigious posting. ${ }^{29}$ With time on his hands, Regino turned his hand to writing. His three surviving scholarly works all date from the period of exile in Trier: De synodalibus $\underline{\text { causis, }}$, his pastoral handbook of canon law (906); the Chronicle (908); and De harmonica institutione, a treatise on music (900-915). ${ }^{30}$ That he remained preoccupied with regaining high office in the kingdom is strongly suggested by the fact that he dedicated each of these works to one of the king's three leading advisers, Hatto, Adalbero and Ratbod respectively. A dark reference to 'our dangerous times' in his prefatory letter to Hatto suggests a mind brooding on past misfortune. ${ }^{31}$ This should encourage us to delve deeper into the Chronicle's allusions and insinuations for further clues as to Regino's part in the contemporary political drama and the causes of his fate.

As an autobiographer Regino is, like Nithard and Gregory, deliberately evasive. Although he detaches himself from the narrative at several points to make methodological comments on his work, the only extended autobiographical passage is the micro-narrative of his entire career entered under 892:

\footnotetext{
${ }^{29}$ He was later remembered there as a good abbot: G.H. Pertz, ed., De abbatia Sancti Martini, MGH Scriptores vol. 8 (Hanover, 1848), 208. St-Maximin was the major monastery in Trier.

${ }^{30}$ W. Hartmann, ed., Das Sendhandbuch des Regino von Prüm (Darmstadt, 2004); M.P. LeRoux, 'The De harmonica institutione and Tonarius of Regino of Prüm', Catholic University of America Ph.D. thesis, 1965. For Regino's musical work see also http://www.chmtl.indiana.edu/tml/9th-11th/9TH-

11TH_INDEX.html

${ }^{31}$ Hartmann, ed., Sendhandbuch, 20-1; Hartmann sees this as an eschatological comment.
} 
At that same time Farabert, abbot of the community of Prüm, set aside his pastoral office voluntarily and with the king's permission and I, although unworthy, succeeded him in charge by the brothers' election, as stipulated by the authority of the Rule. However, I did not remain in that position for very long because at the instigation of my rivals I had to put up with Richar, the brother of Gerard and Matfrid, becoming the hateful successor to my job. I pray that the reader will not find it burdensome if I go back to the beginnings of the matter and set out in plain language how this affair was brought through to its conclusion. For it seems absurd that I, who have set out to explain the actions of others and the causes of events, should pass over in silence a matter that relates to me...

\section{[MISSING SECTION]}

...in particular I ask on bended knee for the reader's pardon since in this account I have been more verbose than is proper. For necessity dictated that I set down in the right order not only what was said but also what was done, because of the scurrilous complaint of those who envy and oppose me. ${ }^{32}$

\footnotetext{
${ }^{32}$ Regino, Chronicle, s.a. 892, 138-9: 'Per idem tempus Farabertus abba Prumiensis cenobii curam pastoralem sua sponte per concessum regis deposuit et ego, quamvis indignus, secundum regularem auctoritatem per electionem fratrum in regimine successi; in quo tamen non diutius immoratus aemulis agentibus Richarium fratrem Gerhardi et Mahtfridi invidiosum mei negotii successorem sustinui. Obsecro autem, ne lectori honerosum videatur, si rem ab origine repetam et, qualiter huiuscemodi negocium ad effectum perductum fuerit, simplici sermone pandam. Absurdum enim videtur, ut, qui aliorum actions et rerum gestarum causas explanare proposui, negotium, quod ad me pertinet, silentio pretermittam
} 
This tantalising passage presents two related editorial problems. The first challenge is to explain the puzzling excision (the only example of such in the $\underline{\text { Chronicle) }}$ which was, to judge by Regino's subsequent reference back to it, fairly substantial. Although we do not have the autograph manuscript, the survival of tenth-century exemplars means that we can establish more or less what the text looked like very early in the transmission process - the earliest extant copy is probably no more than two removes from the original. ${ }^{33}$ In view of this, various suggestions have been made as to the identity of the censor.

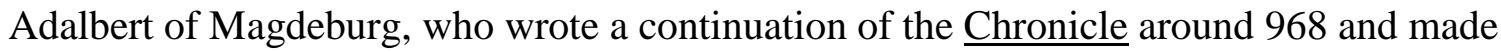
some additions and alterations to the original, is an obvious candidate but can be ruled out because the excisions affect all manuscripts, including those not based on his edition: the censorship must have taken place before he got his hands on it. ${ }^{34}$ Adalbero of Augsburg, from whom Regino solicited feedback in his preface, has been offered as a

...[MISSING SECTION] ... presertim poplitibus veniam posco lectori, eo quod verbosus in hac relatione ultra, quam decuit, extiti. Necessitas enim compulit, ut non solum facta, sed etiam dicta in ordine ponerem propter invidentium et adversantium calumniosam querelam.'

${ }^{33}$ Schleidgen, Überlieferungsgeschichte.

${ }^{34}$ On Adalbert (sometimes referred to as Adalbert of St-Maximin, or of Trier) see M. Frase, Friede und Königsherrschaft (Frankfurt, 1990); T. Kölzer, 'Adalbert von St. Maximin, Erzbischof von Magdeburg (968-981)', Rheinische Lebensbilder, xvii (1997), 7-18; W. Huschner, Transalpine Kommunikation im Mittelalter: diplomatische, kulturelle und politische Wechselwirkungen zwischen Italien und dem nordalpinen Reich (9.-11. Jahrhundert) (Hanover, 2003), 658-85; B. Zeller, 'Die Liudolfinger als fränkische Könige? Beobachtungen zur sogenannten Continuatio Reginonis', in R. Corradini, R. Meens, C. Pössel and P. Shaw, eds., Texts and Identities in the Early Middle Ages (Vienna, 2006), 137-52. 
possible candidate, as have the abbot's political enemies. ${ }^{35}$ These solutions do not entirely satisfy either. Why the former would have fulfilled a conventional request for advice from Regino by deleting a single section and then distributing the mutilated work without further ado is not obvious; nor is it easy to imagine Regino's history-loving persecutors, having forced him into exile, sitting down to add insult to injury by spitefully editing his work (which was not, in any case, yet written in 899). The most obvious solution is that Regino himself was responsible for removing the passage. As Martin Lintzel long ago pointed out, the chronicler himself practically tells us that he changed his mind about his approach as he wrote: the remaining fragment of the original 892 entry advertises Regino's desire to explain his fate in great detail, but by the time he wrote his entry for 899 he had U-turned, referring to his troubles only in passing and claiming selfrestraint inspired by a desire not to bore his audience or to "exaggerate the causes of [his] persecution. ${ }^{36}$ No autograph originals of major historical works survive before that of Richer of Rheims in the late tenth century; but from that manuscript and many that

\footnotetext{
${ }^{35}$ The problem is discussed in most of the literature on Regino cited so far. See also W. Hümpfner, 'Eine unbeachtete Interpolation zu Reginos von Prüms Chronik', Historisches Jahrbuch, xliv (1924), 65-72; K.F. Werner, 'Zur Arbeitsweise des Regino von Prüm', Die Welt als Geschichte, xix (1959), 96-116; O. Prinz, 'Die Überarbeitung der Chronik Reginos aus sprachlicher Sicht', in A. Önnerfors, J. Rathofer and F. Wagner (eds.), Literatur und Sprache im europäischen Mittelalter. Festschrift für Karl Langosch (Darmstadt, 1973), 122-141; Schleidgen, Überlieferungsgeschichte, 88-96.

${ }^{36}$ Regino, Chronicle, s.a. 899, 147; M. Lintzel, 'Zur Chronik Reginos von Prüm', Deutsches Archiv für Erforschung des Mittelalters, i (1937), 499-502.
} 
follow, the phenomenon of authors returning to edit and rewrite sections of their own work is widely attested. ${ }^{37}$

The second problem is the original structure of the 892 annal. Friedrich Kurze, who in the late nineteenth century published what remains the text's standard edition, misleadingly conflated two passages that never appeared together in any manuscript:

- the sentence: 'However, I did not remain in that position for very long because at the instigation of my rivals I had to put up with Richar, the brother of Gerard and Matfrid, becoming the hateful successor to my job' only appears in Kurze's 'A' manuscripts;

- $\quad$ the rest of the paragraph ('I pray... and oppose me') including the gap left by the obliterated lines only appears in Kurze's 'B' manuscripts.

Kurze's provisional assumption that the 'A' group represents the version of the Chronicle edited, interpolated and continued by Adalbert, while the ' $\mathrm{B}$ ' version is closer to Regino's original text, was subsequently vindicated by Otto Prinz's detailed linguistic comparison of the manuscripts. ${ }^{38}$ This opens up the possibility that the text's identification of the Matfridings as Regino's persecutors might have been one of Adalbert's interpolations rather than part of the original work. Later scribes dealt with

\footnotetext{
${ }^{37}$ H. Hoffmann, 'Autographa des früheren Mittelalters', Deutsches Archiv für Erforschung des Mittelalters, lvii (2001), 1-62; J. Glenn, Politics and History in the Tenth Century: the World and Work of Richer of Reims (Cambridge, 2004).

${ }^{38}$ Prinz, 'Überarbeitung'; endorsed by Schleidgen, Überlieferungsgeschichte, pp. 90-1. The general validity of this categorisation rises above the more problematic aspects of Kurze's edition (which in any case Schleidgen concluded to be basically sound).
} 
the omission by ignoring it: they carried on copying without leaving a space, as if the text were perfectly coherent. Nonetheless, there is no doubt that a long section of text was removed, because the following paragraph, securely Regino's, refers back to it. If we attribute to Adalbert the line about the Matfridings, then it might follow that they were also the main subject of the excised section. Regino, scared of offending his stillpowerful foes, thought twice about accusing them directly and deleted his rant; Adalbert, working long after the matter had cooled down, restored them to their original place in the text, albeit more briefly than had Regino.

This reconstruction makes a certain amount of sense, but there are good reasons to reject it. In the first place, one wonders how Adalbert, writing seven decades later, would have known that the Matfridings were to blame for Regino's travails, or why it would have mattered to him enough to mention. What's more, none of Adalbert's other editorial interventions are written in the first person. Indeed, where he referred explicitly to Regino at the start of his continuation he did so in the third person - there was no attempt on his part to pretend that the entire text including the additions was the work of a single author. ${ }^{39}$ There is in fact no reason to doubt that Regino himself added the 'A' sentence on the Matfridings, since it is completely consistent with the 899 entry's implicit but clear reference to Richar's succession having been the result of hostile action. Most likely the line 'However...job' originated as a marginal note subsequently added to the autograph manuscript to replace the excised section, which would explain why it was not

\footnotetext{
${ }^{39}$ On Adalbert's historical thought see now Zeller, 'Die Liudolfinger als fränkische Könige?'; and the brief discussion in MacLean, History and Politics.
} 
transmitted uniformly; such, at any rate, was the fate of other lines entered in the Chronicle's margins. ${ }^{40}$

One implication of this argument is that behind the Matfridings even more powerful forces must have been involved in Regino's deposition. If the lost 892 section had contained accusations against the Matfridings that Regino decided were too direct to remain, then why did he not flinch from accusing Richar in his 899 entry? ${ }^{41}$ Evidently, he felt comfortable pointing his finger straight at Gerard, Matfrid and Richar, but not the 'rivals' at whose 'instigation' they had acted. There are hints elsewhere in the Chronicle that the abbot was worried his work would get him into trouble with influential figures. In his preface he said: 'when I come to the present day, I have restrained my pen so as not to offend certain people who are still alive: I leave posterity to pursue these matters more fully. ${ }^{42}$ This passage verbally resembles part of the 892 entry dealing with Regino's deposition, which he evidently meant his preface to recall. Similarly, under 899, when reflecting again on his replacement as abbot of Prüm, he adds: 'I have refrained from recording here the manner in which this was done against me, lest I appear, perhaps exasperated by injustices beyond the limits allowed by Christian patience, to have

\footnotetext{
${ }^{40}$ For example Regino, Chronicle, s.a. 517-537, 605-11, 26, 31.

${ }^{41}$ See below at nn. 43,81 .

${ }^{42}$ Regino, Chronicle, preface, 1: ‘...ubi ad presentia tempora ventum est, stilo temperavi propter quorundam offensam, qui adhuc sunt superstites, latius haec posteris exequenda relinquens.'
} 
exaggerated the causes of my persecution. ${ }^{43}$ Both these comments were written after the excisions were made, and can be seen as Regino's explanation for why he had changed his mind about naming names. Who, then, had he become reluctant to offend?

To approach this question we must first understand some of the subtler aspects of Regino's narrative, in particular his use of juxtaposition. The careful juxtaposition and sequencing of information were standard narrative tools used by early medieval chroniclers and annalists to construct meaning, establish causality and express implicit authorial judgements. ${ }^{44}$ These techniques became even more important to authors who, like Regino, wanted to make political points without causing open offence. The chronicler's reliance on insinuation and juxtaposition to navigate the rocky waters of his situation is built into the very fabric of Book II's narrative. After the death of Charlemagne, where Regino abandons his verbatim reliance on earlier sources and begins his independent account of Carolingian history, he offers a précis of the rest of his work: Concerning the times of the emperor Louis [the Pious, 814-40] I have included very little because I have not found written texts, nor heard from the elders anything that was worth committing to memory. However, I have more to say about the deeds of the emperor Lothar [I, 840-55] and his brothers, the kings of the Franks. And

\footnotetext{
${ }^{43}$ Regino, Chronicle, s.a. 899, 147: 'Qualiter autem erga me actum sit, idcirco hoc in loco notare distuli, ne forte iniuriis provocatus ultra, quam christiana patientia permittit, persecutionis meae causas exaggerasse viderer.'

${ }^{44}$ W. Goffart, The Narrators of Barbarian History (AD 550-800). Jordanes, Gregory of Tours, Bede and Paul the Deacon (Princeton, 1988); S. Foot, 'Finding the Meaning of Form: Narrative in Annals and Chronicles', in N. Partner, ed., Writing Medieval History (London, 2005), 88-108, esp. 90.
} 
where it comes up to our own times, I have made my narrative broader: 'for things we have seen', as Jerome says, 'are told in one way, and those we have heard in another: those things we know better, we also explain better. ${ }^{45}$

The final section of the tripartite structure outlined here corresponds directly with the

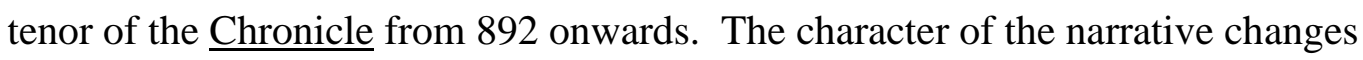
precisely at this point, though it does not become literally 'broader': Regino here stops relating long and detailed anecdotes ('things we have heard') and his entries become decidedly shorter and terser, to the extent that some are little more than unexpanded catalogues of events, the further details of which he perhaps expected his audience to know. These were the 'things we have seen' which had to be told differently from what had preceded. In Regino's scheme, the author's 'own times' thus corresponded explicitly with the period of his abbatial career. Indeed, the chronicler reiterates in the 892 entry itself that the account of his deposition was a turning point in his narrative as well as his career. Immediately after the now lost account of his downfall quoted earlier, Regino writes:

I hope it suffices that I have recorded just a few things of the many that relate to the preceding case and the passing of time. For we have decided to keep quiet concerning the present age because if we write down in clear unclouded fashion the truth about what was done then without doubt we will incur the hatred and

\footnotetext{
${ }^{45}$ Regino, Chronicle, s.a. 813, 73: 'Et de Ludowici quidem imperatoris temporibus perpauca litteris comprehendi, quia nec scripta repperi, nec a senioribus, quae digna essent memoriae commendanda, audivi; de Hlotharii vero imperatoris et fratrum eius regum Francorum gestis plura descripsi. Ubi vero ad nostra tempora ventum est, latius narrationis sermonem protraxi: "aliter enim”, ut Ieronimus ait, "narrantur visa, aliter audita; quae melius scimus, melius et proferimus.",
} 
displeasure of certain people who are still alive. If, on the other hand, we hold back from the truth and write about the case other than it really was, we will incur a reputation as a flatterer and liar, since the affair is known to almost everyone. We therefore leave this to posterity to be explained more fully. But so that we may not be accused of having left it completely untouched, we will undertake to record only some of the events, and in summary. ${ }^{46}$

Regino's use of the future tense in the final sentence is striking. The Chronicle's entries after 892 , he implies, are to be read not just as an account of 'the present age', but also as a constituent part of the account of 'what was done', namely his own persecution ('the affair', 'the case'). Because of Regino's need for a balance between venting his outrage and avoiding offence, we are implicitly invited to look for insinuation and allusion in the Chronicle's remaining entries.

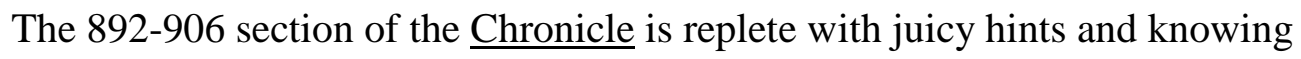
juxtapositions that constitute Regino's guarded commentary on recent events. The entry for 898, for example, states: 'Zwentibald, I know not on whose instigation, cast from his

\footnotetext{
${ }^{46}$ Regino, Chronicle, s.a. 892, 139: 'Haec de retroactis causis transcursisque temporibus ex multis pauca commemorasse sufficiat. Nam de modernis temporibus idcirco reticere disposuimus, quia, si veritatem rerum gestarum ad liquidum stilo executi fuerimus, proculdubio odium et offensam quorundam, qui adhuc superstites sunt, incurremus; si autem a veritate recedentes aliter, quam causa se habeat, scripserimus, nihilominus adulationis et mendatii notam incurremus, quia omnibus pene res cognita est. Posteris ergo hoc latius explanandum relinquimus; se ne haec per omnia inacta preterisse culpemur, res tantum gestas ex parte summatim adnotare curabimus.' Note the verbal similarity to the passage from the preface cited above at n. 42 .
} 
side dux Reginar, who was his most faithful and only counsellor, and after prohibiting him from the offices and hereditary possessions which he held in his kingdom he ordered him to leave the realm within fourteen days. ${ }^{47}$ Reginar was a power in the land: count in Hainault and Hesbaye (modern Belgium) and lay abbot of Echternach, he also had royal blood inherited from his mother, a daughter of Emperor Lothar I. The chronicler's coyness about Reginar's fall from grace is likely to have been diplomatic since the count's rise to prominence at Zwentibald's court had taken place partly at the expense of Archbishop Ratbod of Trier, Regino's own patron, who may thus have been complicit in his exile. ${ }^{48}$ Later in the 898 entry, we are given the intriguing but opaque information that Charles the Straightforward - now king of west Francia in succession to Odo stayed at Prüm during his invasion of Lotharingia in that year, and sent forces from there against Zwentibald. Earlier in the Chronicle Regino went out of his way to emphasise Charles's royal status by stressing the resonances of his name: '[His mother] gave him

\footnotetext{
${ }^{47}$ Regino, Chronicle, s.a. 898, 145: 'Eodem anno Zuendibolch Reginarium ducem sibi fidissimum et unicum consiliarium, nescio cuius instinctu, a se repulit et honoribus, hereditatibus, quas in suo regno habebat, interdictis eum extra regnum infra XIIII dies secedere iubet.'

${ }^{48}$ On Reginar see also Annales Vedastini, ed. B. von Simson, MGH SRG (Hanover, 1909), s.a. 895, 898, 76, 80; Schieffer, ed., Die Urkunden Zwentibolds, nos. 7 and 17; Hlawitschka, Lotharingien, 172-80, 18890; R. Barth, Der Herzog in Lotharingien im 10. Jahrhundert (Sigmaringen, 1990), 15-38; G. Hope, 'The Political Development of the Carolingian Kingdom of Lotharingia, 870-925', University of Glasgow Ph.D. thesis, 2006, 188-233. On the rivalry between Reginar and Ratbod see H. Beumann, 'König Zwentibolds Kurswechsel im Jahre 898, Rheinische Vierteljahrsblätter, xxxi (1966/7), 17-41; and the critique of Beumann's argument in Hlawitschka, Lotharingien, 175, n. 60.
} 
the name of his grandfather, and ordered that he be called Charles. ${ }^{49}$ At the same time he implicitly cast doubt on the legitimacy of the king's half-brothers by insinuating doubts about the propriety of their parents' marriage. ${ }^{50}$

These allusions seem to nod towards Regino's approval of Charles and Reginar, but leave us guessing as to the precise nature of his sympathies. His favourable representation of Odo, king of west Francia until 898, is clearer. ${ }^{51}$ In his account of Odo's accession in 888, Regino describes him as 'a vigorous man who exceeded the others in beauty of form, stature of body and greatness of power and wisdom'. 52 'The others' in question were the other post-888 kings, and the qualities in which he exceeded them consisted of the kingly attributes ascribed by the second-century author Justin, epitomist of the Philippic Histories of Pompeius Trogus, to the friends and successors of Alexander the Great. $^{53}$ By quoting Justin silently but directly, and restricting the parallel to Odo alone,

\footnotetext{
${ }^{49}$ Regino, Chronicle, s.a. 878, 114: 'quae tempore pariendi expleto enixa est puerum, cui nomen avi imposuit eumqu Carolum vocitari fecit.'

${ }^{50}$ Their persecution of Boso (Regino, Chronicle, s.a. 879, 114-15), towards whom Regino was very sympathetic, further hints at his disapproval.

${ }^{51}$ Werner's arguments that Regino was Odo's relative are interesting, but rely on a long and rather stretched chain of reasoning: K.-F. Werner, 'Les premiers Robertiens et les premiers Anjou (IXe siècle début Xe siècle)', in O. Guillot and R. Favreau, eds., Pays de Loire et Aquitaine de Robert le Fort aux premiers Capétiens (Poitiers, 1997), 9-67.

${ }^{52}$ Regino, Chronicle, s.a. 888, 130: 'pre ceteris formae pulchritude et proceritas corporis et virium sapientiaeque magnitude inerat.'

53 Justin, Epitome, ed. O. Seel, Epitoma historiarum Philippicarum (Stuttgart, 1972), 13.1.10-11, 103: 'quippe ea formae pulchritude et proceritas corporis et virium ac sapientiae magnitude in omnibus fuit.'
} 
Regino made an implicit comparison that surreptitiously elevated the west Frankish king above his rivals. We can be confident that this allusion would have had resonance for an audience drawn from the Frankish elite, for Justin was an influential historian whose Epitome is known to have been owned by members of the lay aristocracy. ${ }^{54}$ Alexander himself was a figure revered in Carolingian historical consciousness, and stories about him were used in the ninth century to disguise contemporary political comment. ${ }^{55}$ Regino's implicit respect for Odo is reinforced by the Chronicle's long account of the heroic death of his father Robert the Strong at the Battle of Brissarthe (866). ${ }^{56}$

Elsewhere, Regino bathes Odo in flattering light through careful juxtaposition. In 892 he tells the story of a certain Waltgar, identified as Odo's nepos ('relative'/'nephew'), who rebelled against the king and captured the fortress of Laon - Odo defeated him and he was sentenced to death by a 'public judgement'. In the very next sentence we read about the murder of Megingoz, also identified as a nepos of Odo. Whatever Regino knew or didn't know about the details of either case, in his chronicle a stark contrast is drawn

\footnotetext{
${ }^{54}$ On the reception of Justin see McKitterick, History and Memory, 43-4; Airlie, 'Narrative Patterns', 119 20; J. Crick, ‘An Anglo-Saxon Fragment of Justinus's Epitome’, Anglo-Saxon England, xvi (1987), 181-96. Regino's frequent citation of Justin in the Chronicle would have alerted the cognoscenti to look for such hints: M. Manitius, 'Regino und Justin', Neues Archiv, xxv (1900), 192-204.

${ }^{55}$ J. Contreni, “"By lions, bishops are meant; by wolves, priests”: History, Exegesis and the Carolingian Church in Haimo of Auxerre's Commentary on Ezechiel', Francia, xxix (2002), 29-56, at 46-8. Alexander was one of the heroes painted on the walls of Louis the Pious's palace at Ingelheim, and some origin myths claimed the Franks were his descendants: H. Hummer, Politics and Power in Early Medieval Europe. Alsace and the Frankish Realm, 600-1000 (Cambridge, 2005), 153.

${ }^{56}$ Regino, Chronicle, s.a. 867, 92-3. Similar stories of Robert's heroism circulated in the Rhineland: Annales Fuldenses, ed. F. Kurze, MGH SRG (Hanover, 1891), s.a. 867, 66.
} 
between due process in a public assembly and arbitrary violence in a church; between effective royal intervention in west Francia and its absence in Lotharingia. ${ }^{57}$

The insinuation that Odo's kingly qualities were superior to his contemporaries' was, by extension, a less than flattering comment on the line of east Frankish kings to which Louis the Child belonged. Regino provides most of his late-ninth-century rulers with flattering obituaries which describe their praiseworthy character traits and royal virtues. Two kings, conspicuously, are denied the warm posthumous glow of the abbot's approval. One is Louis the Younger (d. 882), Louis the Child's great-uncle. As with his other obituaries Regino does mention the king's wife and son, also called Louis, but rather than going on to praise him, he continues:

But when...he was staying in Regensburg, that same little boy fell out of the window of the palace and died instantly from a broken neck. This led not only the king and queen but also the whole royal house into great mourning, not just because the death was premature, but also because of its unworthiness. ${ }^{58}$

This could certainly be read as a negative comment on Louis's kingship and line. These events took place, according to Regino, as Prüm was being sacked by a Viking raid. Louis the Younger did nothing to prevent this desecration; and his son's death (coupled in the text with his father's even though it happened two years earlier) can be seen as an expression of divine judgement on his failure - in this lay its 'unworthiness'. The

\footnotetext{
${ }^{57}$ Regino, Chronicle, s.a. 892, 139-40.

${ }^{58}$ Regino, Chronicle, s.a. 882, 118-19: Sed cum...Reganasburh moraretur, idem puerulus de fenestra palacii cecidit et confractis cervicibus statim expiravit; quae non tantum inmatura quam inhonesta mors non solum regi et reginae, verum etiam omni domo regiae maximum luctum ingessit.'
} 
unworthy line of Louis the Younger, who had lingered while Prüm burned, stopped here: from the perspective of c. 908, the known outcome was retrospectively interpreted as revealing divine comment on the course of affairs.

More surprisingly, the other east Frankish king whose death was noted in the $\underline{\text { Chronicle }}$ without an obituary was Arnulf, Louis the Child's father. On the surface, Regino makes a flattering case for Arnulf (an illegitimate son of the Carolingian king Karlmann) as the last heir to the empire of Charlemagne by emphasising the resonances of his name, shared with the Carolingians' saintly ancestor Arnulf of Metz. Yet the argument smacks of special pleading. ${ }^{59}$ In the context of the whole narrative it is little more than a caveat buried within a mini-narrative of the dynasty's dwindling; and the fact that it appears under 880 means that it is subsequently swamped by the crisis of 888 , in which it becomes clear that Arnulf is in truth not the sole heir to the dynasty's power. ${ }^{60}$ From Regino's vantage point decades later, everything was crushed by the inevitable weight of dynastic history moving towards its known outcome. The flattery was further undercut by Regino's reference in the same breath to the king's illegitimate birth - a statement that inevitably recalled the Chronicle's earlier condemnation of Lothar II's irregular sexual

\footnotetext{
${ }^{59}$ M. Becher, 'Arnulf von Kärnten - Name und Abstammung eines (illegitimen?) Karolingers', in U. Ludwig and T. Schilp, eds., Nomen et Fraternitas: Festschrift für Dieter Geuenich zum 65. Geburtstag (Berlin and New York, 2008), 665-82 accentuates, in contrast to the present argument, the positive aspects of Regino's discussion of Arnulf.

${ }^{60}$ Regino, Chronicle, s.a. 880, 116-17. Kortüm, 'Multi reguli', interprets the 888 entry quoted earlier as indicating that Arnulf was not the empire's 'natural lord'; although this would further the present argument, his translation is somewhat riskier than the traditional interpretation.
} 
behaviour and the consequent illegitimacy of his son Hugh. The description of Arnulf's seizing of Rome by force in 896 is also less than triumphant. According to Regino: 'This had been unheard of in previous centuries, because it had never happened except a single time when, a long time before the birth of Christ, the Galli Senones did it under their leader Brennus. ${ }^{61}$ This is particularly odd since Book I of the Chronicle does mention the sack of Rome by Alaric the Goth in $410 .{ }^{62}$ Careful readers were surely expected to notice this glaring omission, and to have their attention drawn to the parallel by the very fact that Regino neglected to mention it. Comparison with Brennus or Alaric did not reflect well on Arnulf. ${ }^{63}$ As if to make this clear, the chronicle juxtaposes Arnulf's taking of Rome with his falling seriously ill. Finally, Regino's ambivalence towards the king surfaces in his description of contemporary conflicts. In 893, when Arnulf backed Charles against Odo in the struggle for the west Frankish crown, the result was a victory for Odo without even a battle; yet the toing and froing of the armies, said Regino, who described Charles as a usurper, produced 'prodigious evils, countless acts of rapine and continuous plunder. ${ }^{94}$ In 894 Arnulf invaded Italy, murdered his opponents and spread

\footnotetext{
${ }^{61}$ Regino, Chronicle, s.a. 896, 144: 'Quod retro ante seculis ideo inauditum, quia non factum fuit, excepto quod Galli Senones cum Brenonne duce multo ante nativitatem Christi tempore semel fecerunt.'

${ }^{62}$ Regino, Chronicle, s.a. 364-369, 17. Book I's dates are usually incorrect.

${ }^{63}$ Brennus is mentioned in less than flattering terms by three of Regino's most authoritative sources: Bede, De Temporum Ratione, in C.W. Jones, ed., Bedae opera didascalia 2, Corpus Christianorum Series Latina vol. 123B (Turnhout, 1977), c. 66, 487; Paul the Deacon, Historia Langobardorum, ed. G. Waitz, MGH SRG (Hanover, 1878), II.23, 101-2; Justin, Epitome, 24.6-8, 32.3.6, 163-6, 195-6. There is a much more celebratory description of Arnulf in Rome in Annales Fuldenses, s.a. 896, 127-9.

${ }^{64}$ Regino, Chronicle, s.a. 893, 141.
} 
fear, before wreaking similar destruction in Burgundy. ${ }^{65}$ By describing the consequences of Arnulf's actions in terms of violence and disorder, he implicitly contrasted him with rulers like Karlmann and Louis the German (his father and grandfather), whose power was built on the maintenance of internal peace through due process and legitimate forms of expansionary violence. Given that his work was destined for the court of the dead king's son, the faint praise showered on Arnulf by Regino is almost as damning as a hostile critique.

Regino's knowing representations of and comments about contemporary rulers were clearly intended to have some political resonance, and modern historians have scoured

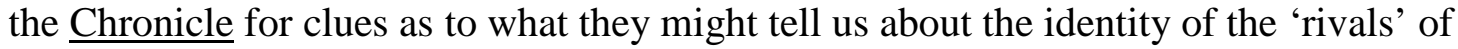
whom the abbot professed himself scared. Most commentators have lined up behind one of three propositions: that Regino was scared of the powerful count Reginar whose deposition is coyly mentioned under 898; that he was a client of Reginar and therefore scared of Zwentibald; or that his sympathy for Odo earned him the hostility of Charles. ${ }^{66}$

\footnotetext{
${ }^{65}$ Regino, Chronicle, s.a. 894, 142.

${ }^{66}$ See for example (and in addition to most of the works on Regino already cited): von den Brincken, Studien, 129; Werner, 'Arbeitsweise', 113-16; Hlawitschka, 'Regino', 14-15; W. Haubrichs, Die Kultur der Abtei Prüm zur Karolingerzeit (Bonn, 1979), 74; M. Hartmann, 'Lotharingien in Arnolfs Reich: das Königtum Zwentibolds', in Fuchs and Schmid, eds., Kaiser Arnolf, 122-42. Wisplinghoff, 'Untersuchungen' offers a clever interpretation of the affair as an internal reaction to abbatial incompetence but underrates the volatile political context, depends on arguments from silence, and presumes that regular ecclesiastical procedures would have operated during Regino's deposition. In any case, the worlds of the monastic community and the political elite overlapped: a man named Matfrid had recently held the senior rank of praepositus (prior), and the brotherhood contained others with names characteristic of the same
} 
Yet we have to be wary of distilling a rigidly partisan political programme from the Chronicle's ambiguous discussions of various rulers. Throughout the work, Regino's evaluation of rulers is not polemically aligned in favour of one or other line of kings so much as it is characterised by a general suspicion of secular authority: 'the hearts of kings are greedy and never satisfied', as he put it, again quoting Justin. ${ }^{67}$ Rulers were praised not for worldly achievement but for the purity of their motives and their readiness to submit to God's will; by this measure even Regino's favourites, like Louis the German, were sometimes criticised. ${ }^{68}$ Above all, he saw the lamentable state of the realm in his own day as a manifestation of divine judgement on the deeds of Lothar II, whose scandalous divorce case had contaminated the moral integrity of the kingdom. ${ }^{69}$

Even more importantly, none of the existing theories about the direction of Regino's partisanship takes sufficient account of the fact that he was not writing contemporaneously, in 899 , but rather composed his entire work close to the time of its final entry (906) and dedication (908). ${ }^{70}$ Any interpretation of his political sympathies

family: Tellenbach, 'Konvent'; Wisplinghoff, 'Untersuchungen', 446. The document naming Matfrid as praepositus is H. Beyer, ed., Urkundenbuch zur Geschichte der Mittelrheinischen Territorien vol. 1

(Koblenz, 1860), no. 120; it is dated to 886 by L. Kuchenbuch, Bäuerliche Gesellschaft und Klosterherrschaft im 9. Jahrhundert. Studien zur Sozialstruktur der Familia der Abtei Prüm (Wiesbaden, 1978), 25-6.

${ }^{67}$ Regino, Chronicle, s.a. 866, 90: ‘animi regum avidi et semper inexplebiles'; Justin, Epitome, 38.6.8, 217.

${ }^{68}$ See MacLean, History and Politics for development of this point.

${ }^{69}$ Regino, Chronicle, s.a. 866, 883, 89-90, 121.

${ }^{70}$ The dating evidence is assembled by MacLean, History and Politics. 
has to be triangulated with the situation at the time he was writing about his troubles, not the time in which they actually took place. As we have seen, we also need to take account of Regino's change of heart about how best to represent his own career, which took place after he wrote the 892 entry but before he got to $899 .^{71}$ This takes us back to the question of how the abbot wrote, and in particular why he censored the original explanation of his own fate. The standard identifications of Regino's enemies make little sense in the context of 906/8, by which time Odo and Zwentibald were long dead, Charles the Straightforward had no direct influence in Lotharingia, and Reginar was back in favour at court. Although we can imagine the chronicler feeling safe enough to have made open accusations in the first draft of his 892 entry against dead or absent kings, it is difficult to see why he would subsequently have changed his mind and become scared enough to alter his text. Similarly, it seems unlikely that he would have used that first draft to compose an open diatribe against Reginar, who was a powerful figure under Louis the Child and once more an ally of Ratbod of Trier, Regino's own patron. Historians have surely been posing the wrong question in trying to use the Chronicle to recover its author's political sympathies in 899 , for his thoughts and loyalties at that date are nowhere recorded. Instead, we need to ask two different but linked questions: who was powerful enough in 899-900 to have authorised a change of leadership at such an important imperial monastery? and what happened as Regino was writing his text c. 906/8 to make him change his mind about the way he had described the circumstances of his ejection from Prüm?

\footnotetext{
${ }^{71}$ See above at n. 36.
} 
The crucial entry for 899 - the year of Regino's expulsion - can be analysed in light of the first of these considerations. Here we are offered another tantalising insight into the circumstances of the abbot's fate:

In the year of the Lord 899, Zwentibald held an assembly with the leading men of Arnulf, Charles, and his own men, at St-Goar. Taking part from Arnulf's realm were Archbishop Hatto and the counts Conrad and Gebhard, and from that of Charles Bishop Askericus and Count Odacar. The outcome of the matter afterwards showed more clearly to the light what was discussed at that meeting in private and outwith the king's presence. $^{72}$

This summit was called to sort out once and for all the disorder presided over by Zwentibald, who had by now taken to hitting leading members of the episcopate on the head with their own staffs. ${ }^{73}$ The public business of the St-Goar assembly reportedly involved Charles making peace with Zwentibald after their recent confrontation. ${ }^{74}$ Yet the interests of those in attendance may have led them to sanction 'in private' a more definitive solution. Arnulf lay on his deathbed, and the delegation from his court represented the group of magnates best-placed to influence the prospective regime of his

\footnotetext{
${ }^{72}$ Regino, Chronicle, s.a. 899, 146-7: ‘Anno dominicae incarnationis DCCCXCVIIII Zuendibolch colloquium habuit cum optimatibus Arnulfi et Caroli et suis apud sanctum Goarem; ex regno Arnulfi interfuerunt Hattho archiepiscopus, Cuonradus et Gebehardus comites, ex parte Caroli Haschiricus episcopus et Odacar comes. Quid vero in eodem conventu seorsum sine presentia regis pertractatum sit, postea eventus rei luce clarius manifestavit.'

${ }^{73}$ Annales Fuldenses, s.a. 900, 140 (probably referring to the events of 899: Hlawitschka, Lotharingien, 179).

${ }^{74}$ Annales Vedastini, s.a. 899, 81.
} 
only legitimate son Louis the Child. Hatto of Mainz was, as mentioned, a guardian to the young prince - together with Adalbero he had baptised Louis in 893, and thereby assumed the role of co-godfather. ${ }^{75}$ Conrad and his son Gebhard were leading members of the aristocratic family known to historians as the Conradines, whose power in Lotharingia and Thuringia had escalated rapidly and at the expense of more established families thanks to their closeness to Arnulf. ${ }^{76}$ Arnulf's wife Uota, Louis's mother, was a close relative of Conrad. ${ }^{77}$ Charles, who had invaded during the previous year in support of the exiled Reginar, was newly crowned as king in the west and faced considerable challenges there - an alliance with the eastern court and a lasting settlement in the middle kingdom involving the restoration of his Lotharingian clients like Reginar and Odacar was clearly in his interests. ${ }^{78}$ In view of all these circumstances, there can be little doubt that the secret agreement made at St-Goar was concerned with the prospective succession in Lotharingia of Louis the Child. It may very well (in light of Regino's knowing

\footnotetext{
${ }^{75}$ Annales Fuldenses, s.a. 893, 122.

${ }^{76}$ See Regino, Chronicle, s.a. 892, 897, 902, 903, 906, 140, 145, 149, 150-2; Innes, State and Society, 230. The protracted historiographical debate about the Conradines' genealogy does not affect the present argument: see D. Jackman, Criticism and Critique: Sidelights on the Konradiner (Oxford, 1997); E. Hlawitschka, Konradiner-Genealogie, unstatthafte Verwandtenehen und spatottonisch-fruhsalische Thronbesetzungspraxis (Hanover, 2003).

77 T. Reuter, Medieval Polities and Modern Mentalities, ed. J.L. Nelson (Cambridge, 2006), 220-3 assembles the evidence and expresses some reservations about the traditional identification of Uota as Conrad's sister; Offergeld, Reges pueri, 566-9 suggests they were cousins.

${ }^{78}$ On Odacar see Hlawitschka, Lotharingien, 166, 168; U. Nonn, Pagus und Comitatus in Niederlothringen (Bonn, 1983), 242.
} 
comment about 'the outcome of the matter') have included a plan to depose Zwentibald, and perhaps even to have him killed. ${ }^{79}$

Although he doesn't say so, Regino must also have been involved: St-Goar, which lay on the Rhine south of Koblenz, was an important dependency of Prüm. ${ }^{80}$ His account of the assembly is thus somewhat disingenuous. It is also oddly un-celebratory and rather bitter considering the meeting led to the removal of a king whom he regarded as an appalling corrupter of the kingdom. Regino's disillusionment may be illuminated by his positioning of the St-Goar summit in the text. The indirect reference to the results of the meeting being manifest in 'the outcome of the matter' reflects Regino's deliberate change of rhetorical strategy since he wrote the original version of the 892 entry. There, the historian had stated he was going to explain everything in great detail; here, by contrast, he advertised his restraint and appealed to the authority of the sequence of events. In his sequencing of those events, what happened next was this:

In that same year Richar was made abbot of the monastery of Prüm. However, I have refrained from recording here the manner in which this was done against me, lest I appear, perhaps exasperated by injustices beyond the limits allowed by

\footnotetext{
${ }^{79}$ Hlawitschka, Lotharingien, 179; T. Reuter, The Annals of Fulda (Manchester, 1992), 140, n. 3; Innes, State and Society, 229; Hartmann, 'Lotharingien', 136-7. The alliance between the parties is also indicated by an entry in the Reichenau memorial book: G. Althoff, Amicitiae und Pacta: Bündnis, Einung, Politik und Gebetsgedenken im beginnenden 10. Jahrhundert (Hanover, 1992), 65-6, 251-2; Offergeld, Reges pueri, 526-7.

${ }^{80}$ St-Goar mattered enough to Regino for him to have included an account of its foundation in the Chronicle (s.a. 517-37, 26).
} 
Christian patience, to have exaggerated the causes of my persecution; and lest an account of wordy reasoning, which is intricate and complicated, inspire contempt in my audience. For, as we set out above, we have decided to record the course of events and not to explain their causes in detail by indicating the reasons explicitly. Those of us who strive for brevity in the affairs of other people must guard against the vice of verbosity in [explaining] our own. ${ }^{81}$

Regino's juxtaposition of the St-Goar plot to depose Zwentibald and the reference to his own deposition was not accidental, and can be read as a means of associating the two events, and even insinuating that the one led to the other. The narrative even seems to invite such an interpretation by promising again 'to record the course of events and not to explain their causes in detail by indicating the reasons explicitly'. The course of events was meant to speak for itself, to have a self-evident significance. Regino's fall from grace was, he implied, enmeshed in the process by which plans to install Louis in Lotharingia were set in motion. Conrad, Gebhard and Hatto were without doubt calling the shots in 899 , and if Regino felt sold out by anyone, it was surely them and the king they represented, Arnulf. This may help us understand the Chronicle's underwhelming and ambiguous depiction of the latter.

\footnotetext{
${ }^{81}$ Regino, Chronicle, s.a. 899, 147: 'Eodem anno Richarius abba monasterii Prumiensis constituitur. Qualiter autem erga me actum sit, idcirco hoc in loco notare distuli, ne forte iniuriis provocatus ultra, quam christiana patientia permittit, persecutionis meae causas exaggerasse viderer et ne prolixae rationis oratio, quae multiplex atque perplexa est, fastidium inferret audientibus. Res enim gestas, ut supra premisimus, notare statuimus, non rerum gestarum causas certis rationum indiciis enucleare. Et qui in aliorum actionibus brevitati studemus, in nostris verbositatis vitium cavere debemus.'
} 
This reading of the text is lent independent support by circumstantial evidence linking the St-Goar meeting and events at Prüm in 899. For a start, the men who were subsequently empowered to kill Zwentibald - Stephen and the Matfridings - were precisely the same men who effected Regino's downfall. This faction must have been backed by the Conradines in 899-900. Although their loyalties were never fixed, Gerard, Matfrid and Stephen had been in Zwentibald's good books since 897, and in 898 apparently offered him material aid in his efforts to repel Charles's invasion from the west. ${ }^{82}$ By August 900, when they killed Zwentibald in battle, they had clearly switched sides. This was a scandalous event whose impact drew comment from the archbishops of Cologne and Rheims and even the pope. ${ }^{83}$ It is inconceivable that the killing could have been carried out, and been allowed to pass unpunished, without the tacit complicity of the court, and in particular of those who were in a position to influence events in Lotharingia: the powerful Conradines. Tellingly, Regino's account connects the arrival of Louis with the murder of Zwentibald, reporting both events in the same sentence. ${ }^{84}$ The unpunished killing of a king by a non-king was unprecedented in Carolingian history. Even when the death was accidental, as in the hunting accidents that did for Charles of Provence and Carloman II,

\footnotetext{
${ }^{82}$ Hlawitschka, Lotharingien, 173, based on the fact that Zwentibald went to Flörchingen - Matfriding territory - at a key stage of the struggle.

${ }^{83}$ R. Le Jan, 'L'aristocratie lotharingienne: structure interne et conscience politique', in Herrmann and Schneider, eds., Lotharingia, 71-88, at 79. Hatto wrote to the pope in summer 900 to justify Louis's succession: H. Bresslau, 'Der angebliche Brief des Erzbischofs Hatto von Mainz an Papst Johann IX.', in Historische Aufsätze Karl Zeumer zum 60. Geburtstag (Weimar, 1910), 9-30; Offergeld, Reges pueri, 52932.

${ }^{84}$ Regino, Chronicle, s.a. 900, 148.
} 
both reported by Regino, the men responsible were forced to flee in fear of retribution. ${ }^{85}$ The marriage subsequently contracted by Gerard with Zwentibald's widow Oda, herself an aristocrat of very high standing, would have needed the same level of assent. It is also worth noting that Zwentibald was buried at the Prüm dependency of Susteren, implying that the monastery's new proprietors, the Matfridings, organised the dead king's funeral. ${ }^{86}$ The funerals of kings were performances of high political drama whose orchestration was carefully controlled by those who wished to lay claim to the deceased's inheritance.$^{87}$ Richar and his brothers may have staged the ceremony as an act of atonement for the killing; but again, it is unthinkable that they would have been able to carry this out without the approval of Louis the Child's backers. ${ }^{88}$ The connections between the Matfriding party and the east Frankish court are confirmed, finally, by a charter recording significant negotiations held at the royal palace of Tribur about lands belonging to the monastery of Fulda, which reveals that Stephen was working closely with Conrad and his allies at a high political level by 900 at the latest. ${ }^{89}$

\footnotetext{
${ }^{85}$ Regino, Chronicle, s.a. 870, 884, 101, 121-2.

${ }^{86}$ On Susteren see Schieffer (ed.), Die Urkunden Zwentibolds, no. 2; Haubrichs, Kultur, 34; Wisplinghoff, 'Untersuchungen', 463-4; Hartmann, 'Lotharingien', 138.

${ }^{87}$ J.L. Nelson, 'Carolingian Royal Funerals', in F. Theuws and J.L. Nelson, eds., Rituals of Power from Late Antiquity to the Early Middle Ages (Leiden and Boston, 2000), 131-84.

${ }^{88}$ P. Fouracre, 'Merovingian History and Merovingian Hagiography', Past and Present, cxxvii (1990), 338 discusses the fostering of saints' cults as a means of coming to terms with the memory of a murdered rival. In this context it is worth noting that a cult of Zwentibald later emerged: T. Bauer, Lotharingien als historischer Raum: Raumbildung und Raumbewusstsein im Mittelalter (Cologne, 1997), 609-22.

${ }^{89}$ E.F.J. Dronke, ed., Codex diplomaticus Fuldensis (Kassel, 1850, reprint Aalen, 1962), no. 647. Note also K. Glöckner, ed., Codex Laureshamensis (Darmstadt, 1929-36), no. 53, which describes an important piece
} 
The Conrad-Hatto court party's adoption of the Matfridings as regional allies is entirely consistent with east Frankish methods of rule in the middle kingdom which, as described earlier, depended on the establishment of powerful middlemen. The delicate balance of interests constructed by Arnulf in Lotharingia was shattered by the events of 899-900, and the consequent power vacuum meant that the court needed a new configuration of alliances. ${ }^{90}$ The Matfridings were clearly best-placed to step into the breach. Just as their stock was rising, Regino's position was becoming increasingly vulnerable: in 898 , he backed the losing horse against Zwentibald by hosting Charles's army at Prüm, and in doing so put himself on the opposite side of the armed struggle from Gerard, Matfrid and Stephen. ${ }^{91}$ When the three counts were empowered in 899 by the Conradine court party, the path was cleared for them to flex their muscles in the region and Prüm suddenly became a tempting and vulnerable target. As Arnulf lay dying and Zwentibald's regime began collapsing around his ears, Regino was stripped of patrons at court who could prevent him becoming another casualty of the struggle for control of Lotharingia. Like Megingoz and Alberic before him, Regino was an actor in this struggle rather than a passive victim: behind his protestations of innocence and persecution surely lurked the

of business relating to the monastery of Lorsch: Adalbero was present as abbot, as were Conrad, Gebhard and Walaho, Stephen's brother. For discussion of these documents see Innes, State and Society, 225, 232.

${ }^{90}$ Arnulf's attempts to balance various groups are described by M. Becher, 'Zwischen König und “Herzog”. Sachsen unter Kaiser Arnolf', in Fuchs and Schmid, eds., Kaiser Arnolf, 89-121. Otto the Illustrious, Zwentibald's father-in-law, was the biggest loser after Arnulf's death.

${ }^{91}$ Regino, Chronicle, s.a. 898, 146. The exile of Reginar may have deprived Regino of a powerful patron at the same time: see above, at n. 66 . 
private knowledge that he had misplayed his hand. We may be fairly certain that the erased version of the 892 entry contained an attempt to justify his actions and re-cast himself as a victim; and that it included a complaint about the Conrad-Hatto group, the only faction in a position to have been complicit in his downfall.

One of the virtues of this hypothesis is that it helps us answer our second question: what happened as Regino was finishing his text to make him scratch out the account of his expulsion and narrow it down to a blunt accusation against the Matfridings alone? The

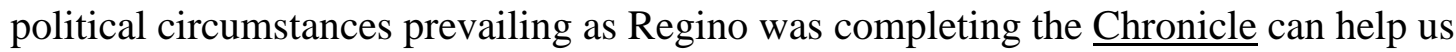
here. In the year 906 the Lotharingian feuding restarted in a new phase. This time, however, the families of Conrad and Matfrid were on opposite sides: Regino's foes of 899 were divided. As he reported:

In the year of the Lord's incarnation 906, Count Conrad sent his son Conrad with a considerable force of armed men to attack Gerard and his brother Matfrid, because they had violently seized his offices and those of his brother Gebhard by taking possession of St-Maximin and St-Mary at Oeren. An army from Lothar's kingdom [i.e. Lotharingia] joined them. They came as far as the Bliesgau, destroying the hereditary lands and possessions of the said brothers and their followers with plunder and burning. Then Gerard and Matfrid petitioned for peace, sending a legation from the fortress in which they had barricaded themselves. After this 
request had been granted until the octave of Easter through the swearing of mutual oaths, the army returned home. ${ }^{92}$

The occupation of St-Maximin and St-Mary in Trier was an audacious and inflammatory move: these monasteries were among the main honores upon which the power of Megingoz and then Zwentibald had been built. ${ }^{93}$ To take control of them was to stake a claim to control patronage and politics in Lotharingia as a whole. This constituted a particular challenge to Gebhard, whose current pre-eminence in the middle kingdom (whether practical or aspirational) had been endorsed through the king's bestowal on him of the title $\underline{\text { dux }} .{ }^{94}$

The Matfridings were soon defeated through a combination of aggression and legal judgement, as Regino goes on to explain, and it is surely no coincidence that his account of these events was chosen as the final entry in the $\underline{\text { Chronicle. }}$. This annal is by far the longest in the last section of the work - it is more than twice as long as any of the other

\footnotetext{
${ }^{92}$ Regino, Chronicle, s.a. 906, 150-1: ‘Anno dominicae incarnationis DCCCCVI Cuonradus comes fiulim suum Cuonradum misit cum armatorum non modica manu, ut irruerent super Gerardum et fratrem eius Matfridum, eo quod honores suos et Gebehardi fratris, videlicet possessionem sancti Maximini et sanctae Mariae ad Horrea, violenter invasissent; quibus exercitus ex regno Lotharii sociatus est. Pervenerunt autem usque in pago Blesiaco, rapinis et incendiis hereditatem et possessionem supradictorum fratrum ac satellitum eorum depopulantes. Porro Gerardus et Matfridus a castro, in quo se communierant, legationem mittentes pacem petierunt; qua concessa datis ex utraque parte sacramentis usque in octavis paschae, exerecitus ad propria discessit.'

${ }^{93}$ Innes, State and Society, 229.

${ }^{94}$ Schieffer (ed.), Die Urkunden Ludwigs des Kindes, no. 20. We must be wary of seeing Gebhard's title as reflecting a constitutionally-defined supremacy: see now Hope, 'Political Development', 217-19.
} 
entries after 892, and three or four times longer than most. Conrad and his family are depicted in glowing, even heroic terms, defeating their enemies through righteous acts of bravery and daring. Conrad's death in battle is lamented. Meanwhile Louis the Child is represented as a paragon of the royal virtues which Regino had spent the rest of Book II establishing, restoring peace by means of public assemblies rather than war, righteously despatching enemies of the common good, and generally acting as a legitimate Carolingian king should. The last substantial paragraph in the entire Chronicle describes Louis dealing definitively with Regino's nemeses, Matfrid and Gerard, by effectively condemning them as outlaws. These textual features and the circumstances which produced them lead us to an explanation for the abbot's act of self-censorship. The fall of the Matfridings in 906 loosened their grip on Trier, where he was writing, and opened to him the possibility of regaining from Richar his old position. The Conradines, now the enemies of his immediate enemies, became potential friends - it was only prudent to remove any complaints he had made about their involvement in his downfall and to point the finger exclusively at Gerard and Matfrid. ${ }^{95}$ By ending his Chronicle with a flattering portrayal of the Conradines' actions that placed their triumph at the culmination of Frankish history, he implicitly endorsed their legitimacy and that of Louis and aligned the resolution of his own plight with the success of their campaign against the Matfridings.

These considerations also allow us to resolve a final puzzle: if Regino intended the Chronicle to end in 906, why was it not dedicated until 908? Despite speculation that

\footnotetext{
${ }^{95}$ That Stephen was not mentioned in the updated version of the 892 entry serves as another indication that the text was altered after the count's death in 901.
} 
entries for 907 and 908 have been lost, the text itself leaves little doubt that 906 was deliberately chosen as the story's endpoint. ${ }^{96}$ The explicit placed immediately after the 906 entry ('Here ends the chronicle of Abbot Regino') survives only in Kurze's 'B' manuscripts, so can be regarded as authorial. Adalbert evidently knew only a version of Regino's text that ended with the 906 annal and the same explicit, since the 'A' version offers an alternative line in the same place ('Thus far Regino. That which follows, we have added') and the continuation begins with $907 .{ }^{97}$ Even setting aside the manuscript evidence, the argument offered here shows that Regino must have first written his 892 entry before the fall of the Matfridings in autumn 906, and that he composed the remaining few pages as a response to that event. In other words, the whole text is likely to have been finished by the end of 906 . To make sense of the two-year gap between completion and dedication, we must therefore find an explanation grounded in contemporary circumstances rather than lost text.

Although the Matfridings were outlawed in 906, the process initiated against them was not completed until 908, when Louis made one of his infrequent trips to Lotharingia. Gerard's properties were formally confiscated and redistributed on 18 January in that year at what must have been a carefully stage-managed court occasion. ${ }^{98}$ The venue was Aachen, the great Carolingian palace described by Regino as 'the seat of the [middle]

\footnotetext{
${ }^{96}$ Doubts as to whether the text is complete are expressed by, inter alia, von den Brincken, Studien, 129.

${ }^{97}$ Regino, Chronicle, s.a. 906, 153-4.

${ }^{98}$ Schieffer, ed., Die Urkunden Ludwigs des Kindes, no. 57. Some of Matfrid's property had been redistributed in 906 while the court was in Nordhausen: no. 51.
} 
kingdom' ${ }^{99}$ It would be surprising if Regino was not present, on his own account or in the entourage of his patron Archbishop Ratbod, who as head of the royal chancery was in charge of drawing up the charters of confiscation. ${ }^{100} 908$ was a general year of reckoning for Louis and his advisers as they sought to draw a line under the violence of the preceding period: later in the year properties belonging to the Babenbergers, another noble family whose rivalry with the Conradines had escalated into open feud, were also confiscated by charter. ${ }^{101}$ This programme of formalized score-settling represented an ideal opportunity for Regino to pitch his own claim for recognition, and to present his work to Adalbero. 908 was also the year of Louis's $15^{\text {th }}$ birthday, a rite of passage for Frankish aristocratic males when they were endowed with sword and belt and formally came of age - what better occasion to present his godfather with an account of the deeds of his relatives and predecessors to guide his kingly conduct? ${ }^{102}$

Regino had another good reason not to have extended his work to 907 in the meantime. The Battle of Bratislava (or Pressburg) fought in that year was the Chronicle's absent presence. The most calamitous Frankish military engagement in living memory, it constituted a comprehensive defeat for the Bavarians at the hands of the ascendant Hungarians, nomadic horsemen who had settled in the Carpathian Basin during the 890s

\footnotetext{
${ }^{99}$ Regino, Chronicle, s.a. 869, 98.

${ }^{100}$ Cf. Schieffer, 'Kanzlei', 128-9.

${ }^{101}$ Schieffer, ed., Die Urkunden Ludwigs des Kindes, no. 60.

${ }^{102}$ I thank Eric Goldberg for this suggestion.
} 
with Arnulf's approval. ${ }^{103}$ This would hardly have been an auspicious note on which to end a text intended for advisers of the presiding ruler. The battle claimed an unusually high death-toll among the nobility and consequently led to a reorientation of structures of power and influence at court. Rudolf Hiestand's analysis of Louis the Child's charters reveals the extent to which some members of the king's inner circle began, after Bratislava, to dominate the distribution of royal patronage even in areas where they had previously had little influence. The main losers were the political networks centred on the now-deceased Liutpold, $\underline{\text { dux }}$ of the Bavarians; the immediate beneficiaries were none other than the Conradines and Bishop Adalbero of Augsburg. ${ }^{104}$ These circumstances throw into even sharper relief Regino's need in 907-8 to gain the support of these men, and through them that of Louis the Child. His canon law collection, written for Ratbod but updated in or shortly after 906 and dedicated to Hatto of Mainz, can be seen as part of the same campaign to ingratiate himself with the movers and shakers at court.

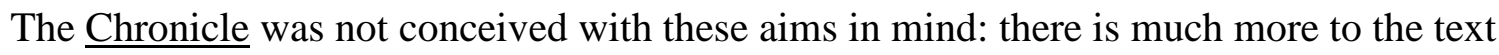
than a plea for recognition. Nonetheless, the events of 906-8 evidently had a material influence on the way it was edited and finished: the importance of contemporary circumstance to the shape of its narrative should not be underestimated. Alas, as a cry for

${ }^{103}$ For the battle see T. Reuter, Germany in the Early Middle Ages, 800-1056 (London, 1991), 129-30; C. Bowlus, The Battle of Lechfeld and its Aftermath, August 955 (Aldershot, 2006), 83-4 (and passim on the Hungarians in this period).

${ }^{104}$ R. Hiestand, 'Pressburg 907. Eine Wende in der Geschichte des ostfränkischen Reiches?', Zeitschrift für bayerische Landesgeschichte, lvii (1994), 1-20. Offergeld, Reges pueri, 563-5, 612-19 modifies but ultimately endorses Hiestand's conclusions. 
help, Regino's submission of his work to Adalbero was a failure - almost everyone involved came out smelling of roses in the end except for the exiled abbot. Richar remained abbot of Prüm and later went on to even greater prominence as bishop of Liège; Conradine power became so well established by 911 that Conrad the Younger (son of the Conrad present at St-Goar, and brother of Gebhard) was able to succeed Louis as king of east Francia and Lotharingia; and even Gerard and Matfrid returned to favour in due course. ${ }^{105}$ Regino, on the other hand, had to be content with marinating in resentment until his death, at Trier, in $915 .{ }^{106}$ His palpable disappointment at the collapse of his own career can be seen as emblematic of the deeper political changes set in motion by the events of 887-8. Regino belonged to the last generation of elite figures whose world view was formed under the umbrella of Carolingian dynastic hegemony. His shock at the events of the 890s may partly reflect his dawning realisation that the rules of the political game were rapidly changing. The post- 888 period shows important continuities with what had preceded, but in certain key respects it was fundamentally different: this was a polycentric world in which the dynastic dispensation was not agreed; in which rulers from different families fought openly and through proxies in a state of almost constant cold war; and in which a reigning king could be killed with impunity. In these respects the factional politics of the 890s look much less like those of the high Carolingian era

\footnotetext{
${ }^{105}$ Gerard probably died alongside Gebhard while fighting the Hungarians in 910, while Matfrid was referred to as count in a charter of 911 . This evidence suggests that they were eventually reconciled with the Conradines and the king, though in reduced circumstances: Hlawitschka, Lotharingien, 191-2 with n. 21.

${ }^{106}$ For his epitaph see Kurze's edition of the Chronicle, vi.
} 
than they do the birth pangs of a long tenth century. ${ }^{107}$ In such circumstances, the incessant side-changing of aristocrats like Matfrid and Gerard and the apparent unpredictability of rulers like Zwentibald can be interpreted as understandable strategies for holding onto power in an age when political structures were becoming increasingly volatile. Men like these were running to stand still. We should resist the temptation to accept uncritically Regino's characterisations of them as faithless persecutors, just as we ought to take with a pinch of salt his own protestations of victimhood.

Despite the importance of Regino's work to modern historians, then, in contemporary politics his was a voice from the margins; without powerful backers at court, he could be easily ignored. The Frankish political landscape was full of such once-powerful casualties: even Nithard, a grandson of Charlemagne himself, was left twisting in the wind after being sold out by his patron. That men like Regino and Nithard integrated stories of personal dissatisfaction into wider histories of the Frankish world helps us understand their plights, but their reliance on allusion, insinuation and self-censorship simultaneously underlines their exclusion from the inner circles of power. They had no guarantee that their narratives would be read sympathetically, or even that they would reach the right audience - hence Regino's fears about causing offence. This suggests an elite milieu in which historiography had a significant role in contemporary political

\footnotetext{
${ }^{107}$ On this theme see also S. MacLean, “"After his death a great tribulation came to Italy...” Dynastic Politics and Aristocratic Factions after the Death of Louis II, c. 870 - c. 890', Millennium Jahrbuch, iv (2007), 239-60.
} 
discourse, but in which frank criticism was potentially dangerous. ${ }^{108}$ At the same time, awkward facts and inconvenient events could not be ignored by historians who expected to be taken seriously. ${ }^{109}$ Allusion and juxtaposition were thus vital techniques for historians who, like Regino, needed to draw attention to injustices suffered without openly antagonising the powerful - men like Conrad, yesterday's enemy, might be tomorrow's patron. In an age of unpredictable factional politics Regino had to retain plausible deniability, meaning that insinuation was often preferable to blunt accusation, and that self-restraint and self-censorship were sometimes needed more than selfjustification. In its own way, it is the very indirectness of authors like the former abbot of Prüm that gives us a grubby window through which we may peer into the smoke-filled backrooms of early medieval politics.

\section{$\underline{\text { University of St Andrews }}$}

SIMON MACLEAN

${ }^{108}$ Cf. J.L. Nelson, 'History-Writing at the Courts of Louis the Pious and Charles the Bald', in A. Scharer and G. Scheibelreiter, eds., Historiographie im frühen Mittelalter (Munich, 1994), 435-42.

${ }^{109}$ G. Althoff, 'Geschichtsschreibung in einer oralen Gesellschaft. Das Beispiel des 10. Jahrhunderts', in B. Schneidmüller and S. Weinfurter, eds., Ottonische Neuanfänge. Symposion zur Ausstellung 'Otto der Große, Magdeburg und Europa' (Mainz, 2001), 151-169; T. Riches, 'Episcopal Hagiography as Archive. Some Reflections on the Autograph of the Gesta episcoporum Cameracensium (MS Den Haag KB75 F15)', Jaarboek voor Middeleeuwse Geschiednis, 10 (2007), 7-46 at 37-42. 